\title{
Evolution of the scholar community in the area of informetrics in Mexico: 1971-2018
}

\author{
María Elena Luna-Morales* \\ Miguel Ángel Pérez-Angón** \\ Evelia Luna-Morales*
}

Artículo recibido:

12 de diciembre de 2020

Artículo aceptado:

16 de junio de 2021

Artículo de investigación

\section{AbStract}

We study the evolution of the Mexican community of researchers active in the field of informetrics studies in the period 1971-2018. Bibliometric data was retrieved from ten databases. 938 documents were registered with a total of 2121 authors affiliated to Mexican institutions. However, $42.2 \%$ of them have a scarce research production during this period. The production profiles of the full sample are organized according to the publications and citations by Mexican scholars, research lines of the authors, evolution of the number of local and foreign scholars, number

* Coordinación General de Servicios Bibliográficos, Centro de Investigación y de Estudios Avanzados del IPN (Cinvestav-IPN), México elena.5280@gmail.com eveorama@gmail.com ** Departamento de Física, Centro de Investigación y de Estudios Avanzados del IPN,
(Cinvestav-IPN), Méxicor mperez@fis.cinvestav.mx mperez@fis.cinvestav.mx

INVESTIGACIÓN BIBLIOTECOLÓGICA, vol. 35, núm. 89, octubre/diciembre, 2021, México, ISSN: 2448-8321 pp. 51-78 
of active and non-active scholars, and members of the National System of Researchers and scientific disciplines. Our findings indicate that a high proportion $(54.5 \%)$ of the authors are members of the National System of Researchers. Our sample of authors include scholars from different areas of knowledge, and the most prolific corresponds to professionals of librarianship and information science. There is an increasing trend in their research production, specifically during the period 1990-2018, but the collaboration network is structured with a minimum set of dominant nodes.

Keywords: Informetrics-Mexico; Scientific Production and Impact; Informetrics-Graduate Studies; Researchers in Informetrics

Evolución de la comunidad académica en el área de informetría en México: 1971-2018

María Elena Luna-Morales, Miguel Ángel Pérez-Angón y Evelia Luna-Morales

\section{RESUMEN}

Se estudia la evolución de la comunidad mexicana de investigadores activos en el campo de los estudios de informetría en el periodo 1971-2018. Los datos bibliométricos se recuperaron de 10 bases de datos distintas. Se registraron 938 documentos con un total de 2121 autores afiliados a instituciones mexicanas. Sin embargo, $42.2 \%$ de ellos tiene una producción de investigación escasa durante este periodo. Los perfiles de producción de la muestra completa están organizados de acuerdo a las publicaciones y citas de académicos mexicanos, líneas de investigación de los autores, evolución del número de académicos locales y extranjeros, número de académicos activos y no activos, miembros del Sistema Nacional de Investigadores y disciplinas científicas. Nuestros hallazgos indican que una alta proporción de los autores $(54.5 \%)$ son miembros del Sistema Nacional de Investigadores. La muestra de autores incluye académicos de diferentes áreas del conocimiento, y la más prolífica corresponde a profesionales de la bibliotecología y las ciencias de la información. Existe una tendencia creciente en su producción investigadora, es- 
pecíficamente en el periodo 1990-2018, pero la red de colaboración se estructura con un conjunto mínimo de nodos dominantes.

Palabras clave: Informetría-Mexico; Producción e Impacto Científico; Graduados en Informetría; Investigadores-Informetría

\section{INTRODUCTION}

Tnformetics has been described by Egghe and Rousseau (1990) as all metric studies related to information science, including bibliometrics, scientometrics and webometrics. This term was originally introduced by Nacke, as well as Blackert and Siegel, in 1979. Informetrics has been considered as the most complete field (Tague-Sutcliffe, 1996) in the area of knowledge associated to the new disciplines in metric studies such as informetry, patentometry and altmetrics (Peters and Bar-Ilan, 2015; Jovanovic, 2012; Hood and Wilson, 2001). The evolution of all these metric disciplines has been studied in recent years (Hérubel, 1999; Gorbea-Portal, 2016; Ball, 2017).

On the other hand, Indranil N. Sengupta (1992) has stressed that this diversity is a natural consequence of the combination of bibliometry, information and library science, science and technology: all these terms may be considered as synonyms in their reach and applications.

Informetrics studies had a steady increase after they were addressed in 1994 by the International Society for Scientometrics and informetrics and of course, other metric disciplines influenced in this increase. Informetrics has been consolidated as a mature field of research with methods and theoretical models we11 defined to characterize the analysis associated to libraries, information centers and the scientific activity in general (Gorbea-Portal, 2016). These studies are complemented with the use of social sciences methods and data visualization, as well as network analysis and science maps (Wolfram, 2015).

We performed a data search on the informetrics (bibliometrics, scientometrics, informetrics, webmetrics, patentometrics and altmetrics) subject in the WoS databases in the last five years of the period studied. We retrieved about 10,000 files on metric studies, $1.4 \%$ of them correspond to Mexican authors. A selection of this sample corresponds to collaborations, communication and scientific policies (Hanel and Mehler, 2019; Uddin, Choudhury, and Hossain, 2019); citation analysis and Hirsch index (Mingers and Leydesdorff, 
2015); bibliometric methodologies (Mandelis, 2019); evaluation of scientific journals and impact factors (Collazo-Reyes, 2014); interdisciplinar and transdisciplinar research (Youngblood and Lahti, 2018); bibliometric indicators, use of new databases and mathematical models (Fischhoff, 2019); theory applications, data visualization, science maps through Pajeck and VosViewer software (Ekanayake, Shen, and Kumaraswamy, 2019; Restrepo-Arango and Urbizagástegui-Alvarado, 2017) and finally cybermetrics, webmetrics and almetrics (Haunschild and Bornmann, 2017), which arised by the impulse of social networks. The almetrics has open the way to another type of indicators associated to the development of the Web 2.0, also known as the second generation of Web services (Peralta-González, Frías-Guzmán, and Gregorio-Chaviano, 2015). They pretend to identify the social processes reproduced in the web by the users and different civil organizations (Ayala, 2014).

In Latin America, the social studies on the scientific production were published in the 1970 decade (Krauskopf, Pessot, and Vicuña, 1986) using the regional databases of Clase and Periodica (Alonso-Gamboa, 2003). The evolution of the scientific activity was also analyzed (Pérez-Angón and Torres-Vega, 1998; Almeida-Filho et al., 2003; Herrero-Solana and Ríos-Gómez, 2006) as well as the quality of the local journals (Bonilla-Marín and Pérez-Angón, 1999).

Scientometrics published in 1995 a special volume on the Latin American studies on science and technology (Cortés-Vargas, 2007). In this volume we can appreciate the consolidation of the research groups from Argentina, Brazil and Mexico. The first Mexican publication on informetrics was published in 1971 by Jorge Robles Glenn from the National Autonomous University of Mexico (UNAM). In particular, the performance of some Mexican scientific communities has been analyzed in the areas of ecology (Castillo, 2000), physics (Contreras-Gómez et al., 2015), engineering (Rodríguez-Miramontes and González-Brambila, 2016), medicine (William, 2001), agriculture (Duarte-Malanski, Schiavi, and Dedieu, 2019) and social sciences (Gil-Antón and Contreras-Gómez, 2017; Contreras-Gómez et al., 2020).

The general aim of the present work is to study the evolution of the Mexican community active in research in the field of informetrics studies. We have studied recently (Luna-Morales, Luna-Morales, and Pérez-Angón, 2021) the effect of local and international collaborations on the research production of this community. Our interest in the present work is to characterize this set of scholars according to their institutional affiliation, their geographical distribution and academic formation. We have identified the authors 
of 938 documents registered in 10 databases, which include Web of Science (WoS) and Scopus. A high fraction of them (54.5\%) is member of the National System of Researchers. Our findings indicate that there is a positive trend of the research production in this area of knowledge, with a high degree of collaboration but that the respective research network is characterized by very few (less then ten) dominant nodes. Accordingly, our research questions can be summarized in two points:

1. How much mature is the research community of Mexican scholars involved in the area of informetrics studies?

2. What are the perspective of this community in terms of the training of new researchers and the generation of strong research networks?

\section{Methods}

We were able to build a bibliometrics database using ten sources of information: Web of Science (WoS) in all Databases (Web of Science Core Collection, Derwent Innovations Index, KCI-Korean Journal Database, Russian Science Citation Index, SciELO Citation Index), Scopus, Google Scholar, Clase, Periodica, Humanindex, Infobila, PubMed, Scielo (https://scielo.org/ es/) and Latindex. We expected to get a stronger data sample by including also local and regional databases in spite the diversity of fields they include and the normalization they require. We retrieved bibliometric data for the period 1971-2018 in the April-June 2019 window in such a way the our 2018 data was already complete. According to our data search, the first paper on informetrics studies was published by Robles-Glenn (1971). Our citation search was restricted only to WoS and Scopus. WoS included already a portion of the Scielo collection. The other databases do not include reliable citations data yet.

We have included in our data search the features "Topics" in the case of WoS, while for Scopus we used the search feature "all fields". On the other hand, we used the advanced search in all other cases with two options: by fields and Boolean operators. In particular, for Scholar we saved the data in CVS.

The search strategy that was applied to retrieve publications in informetrics is shown in Figure 1, in both English and Spanish, both in singular and plural. 

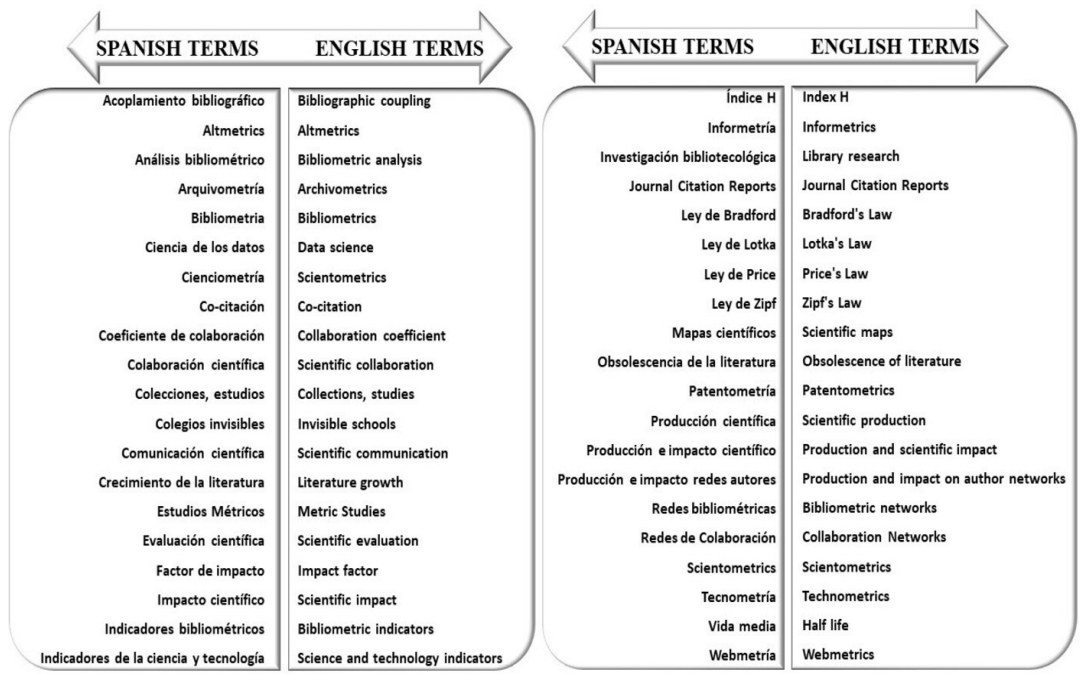

Figure 1. Terminology applied in the search for research publications in Mexico

Our search strategy was completed by identifying journals included in JCR-2018 that published articles on informetrics subjects, in particular those in the subject areas Information science and library science. We also included PLoS ONE and Interciencia. In both cases, we carried out direct searches in their web sites on information disciplines published by Mexican authors. The respective data was registered in Excel with the same WoS data structure.

In order to avoid duplicated papers, we used specific matches for author's names, titles, publication years and bibliographical data. Finally, our search strategy retrieved 938 publications, 542 of them written in Spanish, 381 in English, 11 in Portuguese and 4 in French.

WoS and Scopus data files were retrieved in Excel and CVS formats. In all other cases, the respective files were registered directly and with the same structure used for the WoS and Scopus files. We examined directly each file in order to keep just those associated to the subject area of informetrics studies. We went through the usual process of Normalization of authors names, institutions, scientific disciplines, journal titles and Federal entities. Finally, our data sample was arranged according to the ten general disciplines promoved by the project Atlas de la Ciencia Mexicana (ACM, 2013): biology, physics, chemistry, mathematics, medicine, engineering, humanities, social sciences, geosciences, and agrosciences.

These disciplines were classified according to the subject areas considered in the (SC) field of WoS. Our search was performed in the process of 
selecting members and non-members of NSR in our data sample. This selection used a direct search in the NRS databases and the web pages of their respective institutions. This strategy was used also to identify the author's research areas. Table 1 includes the indicators used in this search strategy. It was necessary to normalize the data on each institution before including it in an Access database.

\begin{tabular}{|c|c|c|}
\hline Indicators & Description & General objective \\
\hline \multirow{3}{*}{ Production } & $\begin{array}{l}\text { Papers on metric } \\
\text { studies }\end{array}$ & $\begin{array}{l}\text { Identification of the production by authors, institutions, } \\
\text { and federal entity }\end{array}$ \\
\hline & $\begin{array}{l}\text { Papers by research } \\
\text { subject }\end{array}$ & $\begin{array}{l}\text { Identification of the production by research subject / } \\
\text { Papers by scientific area (ACM) }\end{array}$ \\
\hline & $\begin{array}{l}\text { Papers by scientific area } \\
\text { (ACM) }\end{array}$ & Identification by scientific area \\
\hline \multirow{3}{*}{ Citation impact } & $\begin{array}{l}\text { Number of citations by } \\
\text { paper }\end{array}$ & Impact factor by author, institution and federal entity \\
\hline & $\begin{array}{l}\text { Number of citations by } \\
\text { subject area }\end{array}$ & Impact factor by subject area \\
\hline & $\begin{array}{l}\text { Number of citations } \\
\text { by scientific discipline } \\
\text { (ACM) }\end{array}$ & Impact factor by scientific discipline \\
\hline \multirow{3}{*}{ NSR/authors } & $\begin{array}{l}\text { Identification of NSR } \\
\text { members }\end{array}$ & $\begin{array}{l}\text { Determination of active/non-active NSR members } \\
\text { Determination of active members by NSR level and aca- } \\
\text { demic area }\end{array}$ \\
\hline & $\begin{array}{l}\text { Identification of addres- } \\
\text { ses of authors }\end{array}$ & Determination of NSR members by federal entity \\
\hline & $\begin{array}{l}\text { Identification of the } \\
\text { NSR academic area of } \\
\text { authors }\end{array}$ & Determination of the production by academic area \\
\hline
\end{tabular}

Table 1. Indicators used to retrieve bibliometric data

Finally, in order to get a well-organized data sample, it was necessary to tolerate double counting with integer values in the fields of name authors and institutions, as well in subject areas and scientific disciplines. We used TI.exe software for co-word mappings of texts (https://www.leydesdorff.net/). The author network was generated with Pajek software (http://mrvar.fdv.uni-lj. si/pajek/). 
The databases of WoS, Scopus and Scholar were pioneer tools in the bibliometric studies published by Mexican scholars. However, some of the first published works in area of knowledge used Clase, Periodica and Latindex (Luna-Morales, Luna-Morales, and Pérez-Angón, 2021). They constituted the first databases with complete bibliometric information in Latin America.

In Figure 2 we used the whole sample (938 documents) to depict the evolution of the number of documents, and the respective generated citations, published in the area of informetrics studies in the period 1971-2018. There is a scarce production during the first three decades with a positive trend in the most recent period 2000-2018. The number of citations is appreciable since 1990 and it is possible to identify five years with an impressive number of citations: 402 (2007), 281 (2014), 264 (2012), 244 (2013) and 210 (2011). They correspond mostly to four papers published in Scientometrics, Interciencia, Journal of the American Society for Information Science and Technology (JASIST) and Research Policy as it is shown in Appendix with the list of the papers that generated the larger number of citations in this period.

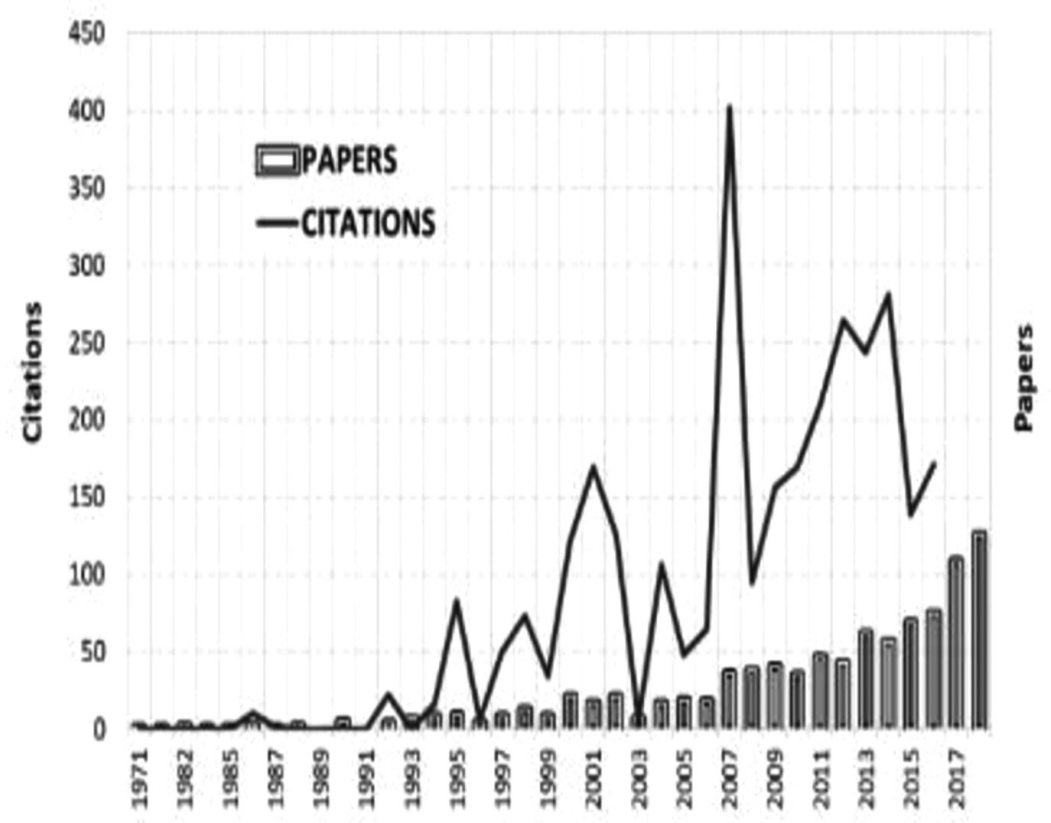

Figure 2. Evolution of the number of publications and citations by Mexican scholars in the field of informetrics (1971-2018) 
In Table 2 we have included the list of the more prolific authors in the field of metric studies of science and technology in Mexico. We were able to identify 1393 active authors in this area of knowledge. There are scholars with different research interests but the most active set of scholars in this field correspond to the area of librarianship.

Table 2 included the 41 most active authors with a minimum of five publications in mainstream journals. Their production corresponds to $22.7 \%$ of the total production in this area of knowledge. This set of authors are affiliated to 14 Mexican institutions which also reflects the fact that field of metric studies of science and technology is a very young area of research. There is other group of 187 scholars that published only 2 to 5 papers with $22.2 \%$ of the total research production. It is important to notice that the rest of the research production $(55.1 \%)$ is associated to 1175 scholars with just one publication.

\begin{tabular}{|c|c|c|c|c|}
\hline Num. & Authors & Institutions & Papers & $\begin{array}{c}\text { Author's research } \\
\text { áreas }\end{array}$ \\
\hline 1 & $\begin{array}{c}\text { Russell-Barnard, Jane } \\
\text { Margaret }\end{array}$ & UNAM & 56 & Librarianship \\
\hline 2 & Licea de Arenas, Judith & UNAM & 46 & Librarianship \\
\hline 3 & Collazo-Reyes, Francisco & Cinvestav & 33 & Librarianship \\
\hline 4 & Luna-Morales, Maria Elena & Cinvestav & 28 & Librarianship \\
\hline 5 & $\begin{array}{c}\text { Macias-Chapula, Cesar } \\
\text { Augusto }\end{array}$ & $\begin{array}{l}\text { Secretaría } \\
\text { de Salud }\end{array}$ & 24 & Librarianship \\
\hline 6 & Gorbea-Portal, Salvador & UNAM & 23 & Librarianship \\
\hline 7 & $\begin{array}{l}\text { Gonzalez-Brambila, Claudia } \\
\text { Noemi }\end{array}$ & ITAM & 21 & Engineering \\
\hline 8 & Aguado-Lopez, Eduardo & UAEMeX & 17 & Sociology \\
\hline 9 & Perez-Angon, Miguel Angel & Cinvestav & 17 & Physics \\
\hline 10 & Valles-Valencia, Javier & UNAM & 16 & Librarianship \\
\hline 11 & Arenas-Vargas, Miguel Angel & UAM & 15 & Biology \\
\hline 12 & Michan-Aguirre, Layla & UNAM & 15 & Biology \\
\hline 13 & Del Rio, Jose Antonio & UNAM & 13 & Physics \\
\hline 14 & Musi-Lechuga, Bertha & UACJ & 13 & Librarianship \\
\hline 15 & Olivas-Avila, Jose Alonso & UACJ & 13 & Medicine \\
\hline 16 & $\begin{array}{c}\text { Alonso-Gamboa, Jose } \\
\text { Octavio }\end{array}$ & UNAM & 12 & Librarianship \\
\hline 17 & $\begin{array}{c}\text { Carrillo-Calvet, Humberto } \\
\text { Andres }\end{array}$ & UNAM & 12 & Engineering \\
\hline
\end{tabular}




\begin{tabular}{|c|c|c|c|c|}
\hline 18 & Tarango-Ortiz, Javier & $\mathrm{UACH}$ & 11 & Librarianship \\
\hline 19 & Luna-Morales, Evelia & Cinvestav & 10 & Librarianship \\
\hline 20 & Rogel-Salazar, Rosario & UAEMeX & 10 & Sociology \\
\hline 21 & Narvaez-Berthelemot, Nora & UNAM & 10 & Librarianship \\
\hline 22 & Cortes, Hector Daniel & UNAM & 9 & Physics \\
\hline 23 & Ainsworth, Shirley & UNAM & 7 & Librarianship \\
\hline 24 & Cocho, Germinal & UNAM & 7 & Physics \\
\hline 25 & Fuentes-Navarro, Raúl & ITESO & 7 & Sociology \\
\hline 26 & $\begin{array}{c}\text { Machin-Mastromatteo, } \\
\text { Juan D. }\end{array}$ & $\mathrm{UACH}$ & 7 & Studies Information \\
\hline 27 & Restrepo-Arango, Cristina & ColMex & 7 & Librarianship \\
\hline 28 & Rodríguez-Salvador, Marisela & ITESM & 7 & Engineering \\
\hline 29 & Cetto-Kramis, Ana Maria & UNAM & 7 & Physics \\
\hline 30 & Becerril-Garcia, Arianna & UAEMex & 6 & Engineering \\
\hline 31 & Roldan-Valadez, Ernesto & $\begin{array}{l}\text { Secretaría } \\
\text { de Salud }\end{array}$ & 6 & Medicine \\
\hline 32 & Ayala-Picazo, Micaela & ColMex & 5 & Librarianship \\
\hline 33 & Cantú-Ortiz, Francisco J. & ITESM & 5 & Engineering \\
\hline 34 & $\begin{array}{l}\text { García-Mandujano, } \\
\text { Esther Ofilia }\end{array}$ & UNAM & 5 & Physics \\
\hline 35 & García-Gómez, Francisco & IMSS & 5 & Medicine \\
\hline 36 & Gonzalez, Eric & UNAM & 5 & Librarianship \\
\hline 37 & Liberman, Sofia & UNAM & 5 & Psychology \\
\hline 38 & $\begin{array}{l}\text { Mercado-Martínez, } \\
\text { Francisco Javier }\end{array}$ & UDG & 5 & Medicine \\
\hline 39 & Miramontes, Pedro & UNAM & 5 & Mathematics \\
\hline 40 & $\begin{array}{l}\text { Reyna-Espinosa, } \\
\text { Felipe Rafael }\end{array}$ & UNAM & 5 & Librarianship \\
\hline 41 & Rios-Castañeda, Camilo & $\begin{array}{l}\text { Instituto Nacional } \\
\text { de Neurología } \\
\text { y Neurocirugía }\end{array}$ & 5 & Medicine \\
\hline
\end{tabular}

Table 2. List of the most productive authors by institution and research area

Figure 3 also shows that the most recent increase in the Mexican output can be associated with a large number of new journals registered in the WoS and Scopus databases (Collazo-Reyes, 2014), as well as to an increase in the number of scholars active in this research field. 


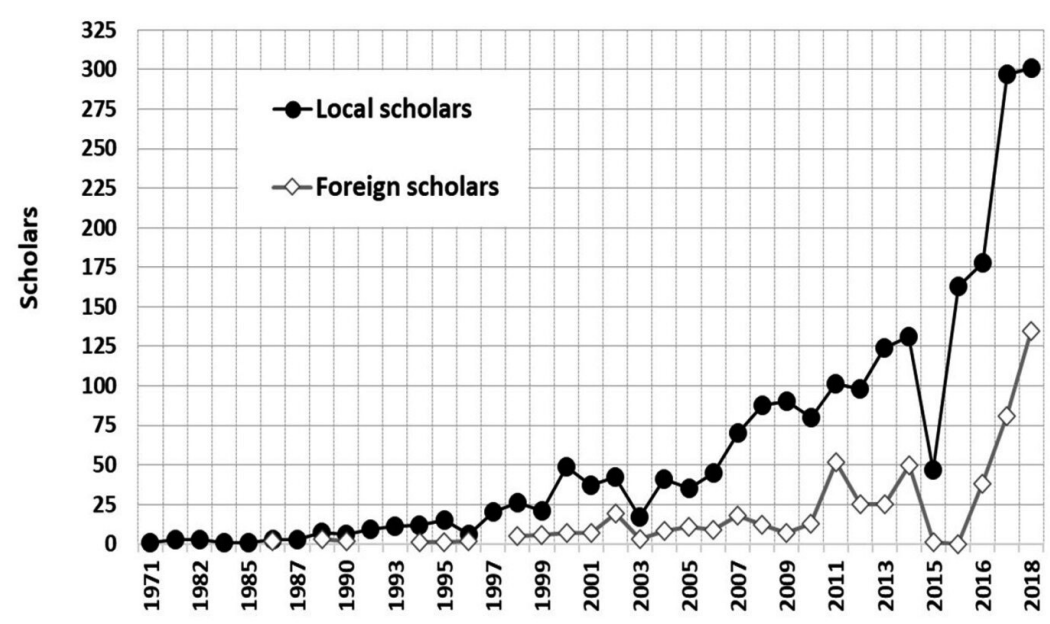

Figure 3. Evolution and comparison of the number of local and foreign scholars in the field of informetrics (1971-2018)

The same figure shows the evolution of the number of local vs. foreign authors in our data sample. It is impressive the dynamics of the number of local authors in this field of research, with an increasing factor of two or three in recent years. However, we found that $42.2 \%$ of the whole set of local authors (951) has a scarce research production with just one or two papers published in the analyzed period. We call inactive authors to the scholars identified with this very low research production (Figure 4).

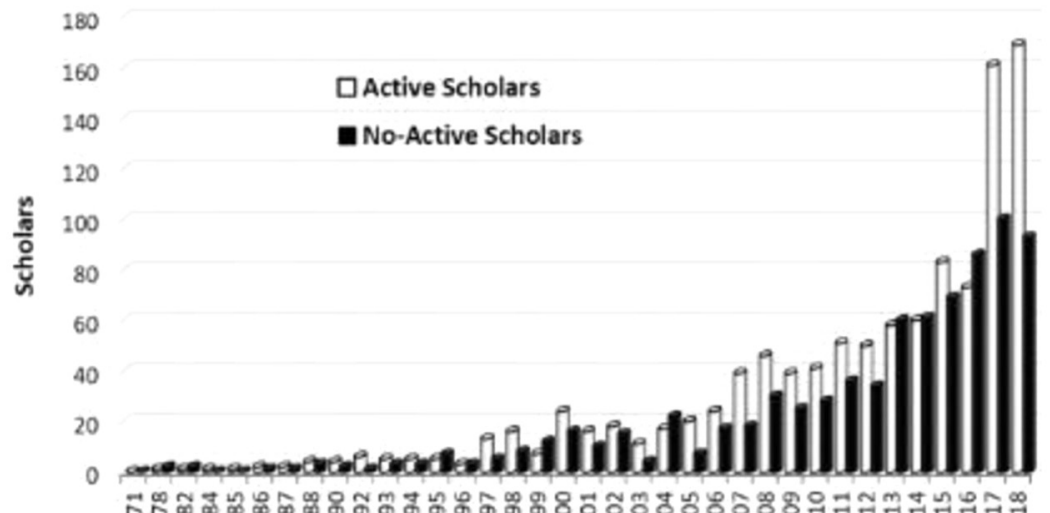

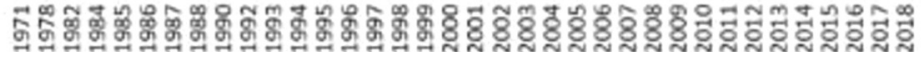

Figure 4. Evolution of the number of active and no-active scholars in informetrics (1971-2018) 
In Figure 5 we present the evolution of the number of authors that are members of the National System of Researchers. We were able to identify a relatively low percentage $(54.1 \%)$ of NSR members in our data sample, which contribute with $43.7 \%$ of the whole production and with $43.4 \%$ of the respective number of citations (Table 2).

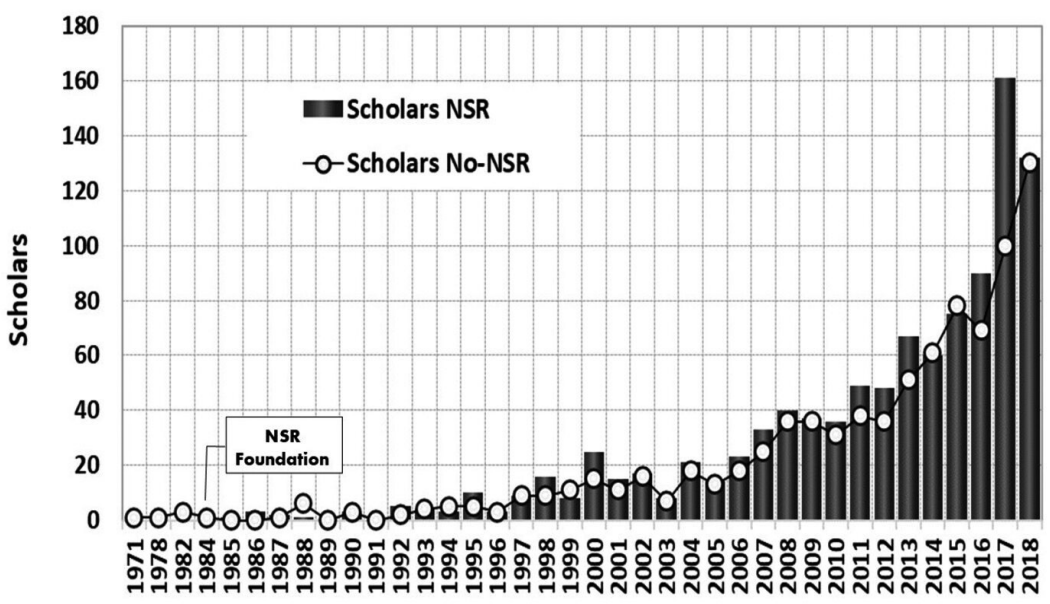

Figure 5. Evolution of the number of scholars which are members or no-members of the National System Research (NSR) in the field of informetrics (1971-2018)

These results are consistent with similar percentages obtained by NSR members in the area of social sciences with respect to the whole research production in this area of knowledge (Contreras-Gómez et al., 2020). We can appreciate that the number of NSR members in our data sample had a strong increase in period 2016-2018. However, this group of NSR authors do not have yet a strong contribution on the whole sample of documents published in the area of informetrics studies. Since NSR was funded in 1984, their first papers appeared in 1985 (Table 3). It is important to notice that there is double counting in Table 2 due to the large number of documents published in collaboration by NSR members and no-members.

\begin{tabular}{|c|c|c|c|c|c|c|c|}
\hline \multicolumn{4}{|c|}{ Members NSR } & \multicolumn{4}{|c|}{ No-Members NSR } \\
\hline Years & $\begin{array}{c}\text { Num. } \\
\text { Scholars }\end{array}$ & $\begin{array}{c}\text { Num. } \\
\text { Papers }\end{array}$ & $\begin{array}{c}\text { Num. } \\
\text { Citations }\end{array}$ & Years & $\begin{array}{c}\text { Num. } \\
\text { Scholars }\end{array}$ & $\begin{array}{c}\text { Num. } \\
\text { Papers }\end{array}$ & $\begin{array}{c}\text { Num. } \\
\text { Citations }\end{array}$ \\
\hline $1971-1975$ & 0 & 0 & 0 & $1971-1975$ & 1 & 1 & 1 \\
\hline $1976-1980$ & 0 & 0 & 0 & $1976-1980$ & 1 & 1 & 0 \\
\hline $1981-1985$ & 1 & 1 & 0 & $1981-1985$ & 4 & 4 & 0 \\
\hline
\end{tabular}




\begin{tabular}{|c|c|c|c|c|c|c|c|}
\hline $1986-1990$ & 9 & 9 & 11 & $1986-1990$ & 10 & 10 & 43 \\
\hline $1991-1995$ & 22 & 30 & 93 & $1991-1995$ & 16 & 17 & 71 \\
\hline $1996-2000$ & 61 & 73 & 257 & $1996-2000$ & 47 & 49 & 77 \\
\hline $2001-2005$ & 75 & 95 & 494 & $2001-2005$ & 65 & 73 & 241 \\
\hline $2006-2010$ & 169 & 201 & 733 & $2006-2010$ & 146 & 161 & 651 \\
\hline $2011-2015$ & 299 & 330 & 873 & $2011-2015$ & 264 & 287 & 778 \\
\hline 2016-2018 & 386 & 455 & 295 & $2016-2018$ & 299 & 325 & 256 \\
\hline TOTAL & 1022 & $\mathbf{1 1 9 4}$ & $\mathbf{2 7 5 6}$ & TOTAL & $\mathbf{8 5 3}$ & $\mathbf{9 2 8}$ & $\mathbf{2 1 1 8}$ \\
\hline
\end{tabular}

Table 3. Relation of the number of publications and citations by members and no-members of NSR in the field of informetrics (1971-2018)

In Table 4 we included the distribution of the number of documents registered in our data sample according to author's research areas. The most frequent areas included in our data sample correspond to librarianship and medicine, with $27.2 \%$ (17.6\%) and $21.6 \%$ (28.7\%) of the documents (citations), respectively. In the following places we found also that engineering and physics have a substantial contribution to our data sample, with $7.4 \%(10.0 \%)$ and $5.4 \%(10.8 \%)$ of the documents (citations).

The large number of documents published by scholars with specialties different from librarianship is associated to their interest in the development of their own research communities, and to the interest in applying some methodologies generated by members of their communities like network analysis, visualization systems and mining data.

\begin{tabular}{|c|c|c|c|c|c|}
\hline Num. & Authors' research areas & Papers & $\begin{array}{c}\text { Cita- } \\
\text { tions }\end{array}$ & $\begin{array}{c}\% \\
\text { Papers }\end{array}$ & \% Citations \\
\hline 1 & Librarianship & 555 & 1564 & 27.2 & 17.6 \\
\hline 2 & Medicine & 441 & 2557 & 21.6 & 28.7 \\
\hline 3 & Engineering & 151 & 894 & 7.4 & 10.0 \\
\hline 4 & Physics & 110 & 962 & 5.4 & 10.8 \\
\hline 5 & Biology & 76 & 424 & 3.7 & 4.8 \\
\hline 6 & Psicology & 51 & 154 & 2.5 & 1.7 \\
\hline 7 & Sociology & 51 & 143 & 2.5 & 1.6 \\
\hline 8 & Mathematics & 49 & 383 & 2.4 & 4.3 \\
\hline 9 & Education & 48 & 62 & 2.4 & 0.7 \\
\hline 10 & Economy & 47 & 217 & 2.3 & 2.4 \\
\hline 11 & Ecology & 43 & 90 & 2.1 & 1.0 \\
\hline
\end{tabular}




\begin{tabular}{|c|c|c|c|c|c|}
\hline 12 & Social Studies & 43 & 124 & 2.1 & 1.4 \\
\hline 13 & Administration & 42 & 160 & 2.1 & 1.8 \\
\hline 14 & Agronomy & 39 & 102 & 1.9 & 1.1 \\
\hline 15 & Chemistry & 29 & 223 & 1.4 & 2.5 \\
\hline 16 & Nursing & 27 & 18 & 1.3 & 0.2 \\
\hline 17 & Veterinary and zootechnics & 24 & 9 & 1.2 & 0.1 \\
\hline 18 & Artificial intelligence & 21 & 169 & 1.0 & 1.9 \\
\hline 19 & Anthropology & 16 & 133 & 0.8 & 1.5 \\
\hline 20 & Vegetal biology & 16 & 107 & 0.8 & 1.2 \\
\hline 21 & Science Studies & 15 & 32 & 0.7 & 0.4 \\
\hline 22 & Aquaculture & 14 & 18 & 0.7 & 0.2 \\
\hline 23 & Social comunication & 13 & 31 & 0.6 & 0.3 \\
\hline 24 & Ecosystems & 13 & 6 & 0.6 & 0.1 \\
\hline 25 & Astronomy & 12 & 4 & 0.6 & 0.0 \\
\hline 26 & Technologies & 11 & 79 & 0.5 & 0.9 \\
\hline 27 & Geophysics & 11 & 64 & 0.5 & 0.7 \\
\hline 28 & Political Sciences & 11 & 5 & 0.5 & 0.1 \\
\hline 29 & Journal editors & 11 & 5 & 0.5 & 0.1 \\
\hline 30 & Manufacture & 10 & 73 & 0.5 & 0.8 \\
\hline 31 & Design & 10 & 43 & 0.5 & 0.5 \\
\hline 32 & Scientific communication & 10 & 28 & 0.5 & 0.3 \\
\hline 33 & Science, Technology and Society & 10 & 11 & 0.5 & 0.1 \\
\hline 34 & Pedagogy & 10 & 2 & 0.5 & 0.0 \\
\hline
\end{tabular}

Table 4. Distribution of the research areas involved in the production of Mexican scholars in the field of informetrics (1971-2018)

In Table 5, there are some scientific disciplines, like physics, medicine and engineering, that have higher percentages of citations as compared with their respective contributions to the number of publications and scholars.

The case of humanities deserves a special comment. This area of knowledge has contributed to the Mexican scientific production with a low number of publications and citations (ACM, 2013). Some of the leading researchers in librarianship are members of NSR in the área V (humanities); as a consequence, they have contributed with an extraordinary number of publications and citations. 


\begin{tabular}{|c|c|c|c|c|c|}
\hline $\begin{array}{c}\text { Num. } \\
\text { Scholars }\end{array}$ & Scientific Discipline & Papers & $\begin{array}{c}\text { Cita- } \\
\text { tions }\end{array}$ & \% Papers & \% Citations \\
\hline 8 & Earth sciences & 8 & 17 & 0.3 & 0.2 \\
\hline 11 & Humanities & 12 & 151 & 0.4 & 1.7 \\
\hline 21 & Chemical sciences & 29 & 223 & 1.1 & 2.5 \\
\hline 40 & Agriculture & 43 & 122 & 1.6 & 1.4 \\
\hline 41 & Mathematics & 50 & 291 & 1.9 & 3.3 \\
\hline 102 & Physical sciences & 172 & 1135 & 6.4 & 12.9 \\
\hline 190 & Biological Sciences & 212 & 512 & 7.9 & 5.8 \\
\hline 222 & Engineering & 315 & 1289 & 11.8 & 14.6 \\
\hline 551 & $\begin{array}{c}\text { Medicine and Health } \\
\text { Sciences }\end{array}$ & 641 & 2595 & 24.0 & 29.5 \\
\hline 661 & $\begin{array}{c}\text { Social Sciences and } \\
\text { Behavioral Sciences }\end{array}$ & 1193 & 2474 & 44.6 & 28.1 \\
\hline & \begin{tabular}{c} 
ToTAL \\
\hline
\end{tabular} & 2675 & 8809 & 100.0 & 100.0 \\
\hline
\end{tabular}

Table 5. Distributions of the number of scholars, publications and citations, according to the scientific disciplines (1971-2018)

The geographical distribution of authors is presented in Tables 6 and 7. There is a very high concentration of scholars in Mexico City (CDMX): $52.2 \%$ that produce $59.4 \%(55.3 \%)$ of the published documents (citations). Only four of the other federal entities (Jalisco, Edo. de México, Nuevo León, Morelos) have percentages higher than $4 \%$. This is a rather dramatic concentration of the research activity in CDMX which has been also observed by other studies in social sciences and humanities (Contreras-Gómez et al., 2020). The same situation is reflected in Table 7 for the authors data in terms of NSR membership.

\begin{tabular}{|l|c|c|c|c|c|c|}
\hline \multicolumn{1}{|c|}{$\begin{array}{c}\text { Geographical } \\
\text { entity }\end{array}$} & $\begin{array}{c}\text { Num. } \\
\text { Scholars }\end{array}$ & $\begin{array}{c}\% \\
\text { Scholars }\end{array}$ & Papers & $\begin{array}{c}\% \\
\text { Papers }\end{array}$ & Citations & $\begin{array}{c}\% \\
\text { Citations }\end{array}$ \\
\hline CDMX & 724 & 52.2 & 1257 & 59.4 & 3913 & 55.3 \\
\hline Jalisco & 91 & 6.6 & 106 & 5.0 & 538 & 7.6 \\
\hline Estado de México & 82 & 5.9 & 107 & 5.1 & 160 & 2.3 \\
\hline Nuevo León & 58 & 4.2 & 80 & 3.8 & 477 & 6.7 \\
\hline
\end{tabular}




\begin{tabular}{|c|c|c|c|c|c|c|}
\hline Morelos & 57 & 4.1 & 101 & 4.8 & 559 & 7.9 \\
\hline Baja California & 50 & 3.6 & 52 & 2.5 & 157 & 2.2 \\
\hline Puebla & 49 & 3.5 & 63 & 3.0 & 140 & 2.0 \\
\hline Chihuahua & 37 & 2.7 & 88 & 4.2 & 404 & 5.7 \\
\hline Tamaulipas & 24 & 1.7 & 26 & 1.2 & 22 & 0.3 \\
\hline Veracruz & 22 & 1.6 & 25 & 1.2 & 85 & 1.2 \\
\hline Yucatán & 21 & 1.5 & 21 & 1.0 & 27 & 0.4 \\
\hline Michoacán & 20 & 1.4 & 24 & 1.1 & 308 & 4.3 \\
\hline Guanajuato & 17 & 1.2 & 17 & 0.8 & 39 & 0.6 \\
\hline Sinaloa & 17 & 1.2 & 17 & 0.8 & 28 & 0.4 \\
\hline Sonora & 16 & 1.2 & 18 & 0.9 & 27 & 0.4 \\
\hline Querétaro & 15 & 1.1 & 15 & 0.7 & 34 & 0.5 \\
\hline San Luis Potosí & 12 & 0.9 & 18 & 0.9 & 17 & 0.2 \\
\hline Tabasco & 10 & 0.7 & 10 & 0.5 & 3 & 0.0 \\
\hline Zacatecas & 10 & 0.7 & 16 & 0.8 & 19 & 0.3 \\
\hline Chiapas & 9 & 0.6 & 9 & 0.4 & 2 & 0.0 \\
\hline Colima & 9 & 0.6 & 9 & 0.4 & 22 & 0.3 \\
\hline Coahuila & 7 & 0.5 & 7 & 0.3 & 6 & 0.1 \\
\hline Hidalgo & 7 & 0.5 & 7 & 0.3 & 14 & 0.2 \\
\hline Durango & 5 & 0.4 & 5 & 0.2 & 29 & 0.4 \\
\hline Quintana Roo & 4 & 0.3 & 4 & 0.2 & 24 & 0.3 \\
\hline Tlaxcala & 3 & 0.2 & 4 & 0.2 & 19 & 0.3 \\
\hline Nayarit & 3 & 0.2 & 3 & 0.1 & 1 & 0.0 \\
\hline Aguascalientes & 2 & 0.1 & 2 & 0.1 & 3 & 0.0 \\
\hline Baja California Sur & 2 & 0.1 & 2 & 0.1 & 0 & 0.0 \\
\hline Campeche & 2 & 0.1 & 2 & 0.1 & 1 & 0.0 \\
\hline Guerrero & 2 & 0.1 & 2 & 0.1 & 3 & 0.0 \\
\hline TOTAL & 1387 & 100 & 2117 & 100 & 7081 & 100 \\
\hline
\end{tabular}

Table 6. Distribution of the scholars by geographical entity in the field of metric studies (1971-2018) 
EVOLUTION OF THE SCHOLAR COMMUNITY IN THE AREA OF INFORMETRICS IN MEXICO:...

\begin{tabular}{|c|c|c|c|c|c|}
\hline \multicolumn{3}{|c|}{ Members NSR } & \multicolumn{3}{|c|}{ No-Members NSR } \\
\hline $\begin{array}{c}\text { Geographical } \\
\text { entity }\end{array}$ & Papers & $\%$ Papers & $\begin{array}{c}\text { Geographical } \\
\text { entity }\end{array}$ & Papers & $\%$ Papers \\
\hline $\operatorname{cDMX}$ & 672 & 56.4 & CDMX & 585 & 63.2 \\
\hline Estado de México & 63 & 5.3 & Jalisco & 47 & 5.1 \\
\hline Nuevo León & 61 & 5.1 & Morelos & 43 & 4.6 \\
\hline Jalisco & 60 & 5.0 & Chihuahua & 40 & 4.3 \\
\hline Baja California & 50 & 4.2 & Puebla & 38 & 4.1 \\
\hline Chihuahua & 47 & 3.9 & Estado de México & 33 & 3.6 \\
\hline Puebla & 45 & 3.8 & Nuevo León & 20 & 2.2 \\
\hline Morelos & 32 & 2.7 & Baja California & 18 & 1.9 \\
\hline Michoacán & 16 & 1.3 & Guanajuato & 10 & 1.1 \\
\hline Veracruz & 15 & 1.3 & Querétaro & 10 & 1.1 \\
\hline Yucatán & 15 & 1.3 & Tamaulipas & 10 & 1.1 \\
\hline Querétaro & 13 & 1.1 & Veracruz & 9 & 1.0 \\
\hline San Luis Potosí & 12 & 1.0 & Sinaloa & 8 & 0.9 \\
\hline Tabasco & 12 & 1.0 & Tabasco & 8 & 0.9 \\
\hline Tamaulipas & 12 & 1.0 & Michoacán & 5 & 0.5 \\
\hline Sonora & 11 & 0.9 & San Luis Potosí & 5 & 0.5 \\
\hline Sinaloa & 10 & 0.8 & Zacatecas & 5 & 0.5 \\
\hline Zacatecas & 10 & 0.8 & Chiapas & 4 & 0.4 \\
\hline Chiapas & 6 & 0.5 & Yucatán & 4 & 0.4 \\
\hline Coahuila & 5 & 0.4 & Durango & 3 & 0.3 \\
\hline Hidalgo & 5 & 0.4 & Hidalgo & 3 & 0.3 \\
\hline Colima & 4 & 0.3 & Nayarit & 3 & 0.3 \\
\hline Guanajuato & 4 & 0.3 & Quintana Roo & 3 & 0.3 \\
\hline Aguascalientes & 2 & 0.2 & Campeche & 2 & 0.2 \\
\hline Campeche & 2 & 0.2 & Coahuila & 2 & 0.2 \\
\hline Durango & 2 & 0.2 & Colima & 2 & 0.2 \\
\hline Quintana Roo & 2 & 0.2 & Guerrero & 2 & 0.2 \\
\hline Tlaxcala & 2 & 0.2 & Sonora & 2 & 0.2 \\
\hline Baja California Sur & 1 & 0.1 & Aguascalientes & 1 & 0.1 \\
\hline
\end{tabular}




\begin{tabular}{|c|c|c|c|c|c|}
\hline & & & Baja California Sur & 1 & 0.1 \\
\hline TOTAL & 1191 & 100 & TOTAL & 926 & 100 \\
\hline
\end{tabular}

Table 7. Geographical distribution of the number of publications by NSR members in the field of metric studies (1971-2018)

In Figure 6 we have depicted the collaboration network obtained from our data sample in the informetrics studies. We can appreciate two main subnetworks associated to Jane Margaret Russell Barnard and Judith Licea de Arenas, two of the pioneers in this research field. They are affiliated to the National University of Mexico (UNAM). Most of their collaborations shown in Figure 6 involve their own graduate students. Another aspect of interest in Figure 6 is the very low (less than ten) dominant nodes, which induce a large vulnerability of the network. We used the Leydesdorff and Pajeck softwares in order to construct this collaboration network.

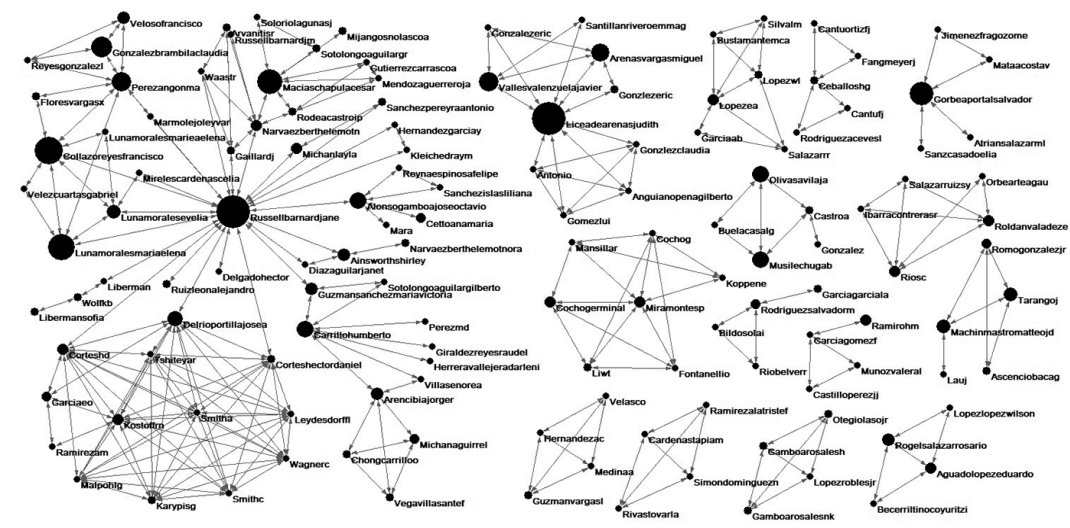

Figure 6. Co-authorship network of Mexican scholars in the field of informetrics (1971-2018)

There are eight training institutions with graduate programs in the field of informetrics (Table 8). Most of these programas require presencial participation of students. UNAM was the pioneer institution in these graduate programs in Mexico with both master and $\mathrm{PhD}$ programs. For this reason, three of the dominant nodes in the collaboration network shown in Figure 6 correspond to UNAM faculty members (Russell Barnard, Licea de Arenas, and Gorbea Portal). It has been pointed out also that the training of new researchers has a positive effect on the development of strong research groups. 


\begin{tabular}{|c|c|c|c|c|}
\hline Num. & Institutions & Graduate programs & $\begin{array}{l}\text { Begin } \\
\text { Year }\end{array}$ & Learning Unit Character \\
\hline \multirow{3}{*}{1} & \multirow{3}{*}{$\begin{array}{c}\text { Universidad Nacional } \\
\text { Autónoma de México } \\
\text { (UNAM) }\end{array}$} & $\begin{array}{l}\text { Master in librarianship } \\
\text { and Information Science }\end{array}$ & 1998 & Virtual \\
\hline & & $\begin{array}{l}\text { Master in librarianship } \\
\text { and Information Science }\end{array}$ & 2000 & Presential \\
\hline & & $\begin{array}{l}\text { PhD in librarianship and } \\
\text { Information Science }\end{array}$ & 2006 & Virutal \\
\hline 2 & $\begin{array}{l}\text { Universidad Autónoma } \\
\text { Metropolitana (UAM-X) } \\
\text { - Universidad de la } \\
\text { Habana - Universidad } \\
\text { de Murcia, España }\end{array}$ & $\begin{array}{l}\text { Master/PhD } \\
\text { in Information } \\
\text { Magnagement }\end{array}$ & 2006 & Virtual \\
\hline 3 & $\begin{array}{c}\text { Instituto Tecnológico } \\
\text { de Estudios Superiores } \\
\text { Monterrey } \\
\text { (Campus Hidalgo) }\end{array}$ & $\begin{array}{c}\text { Master, Information } \\
\text { Science and Knowledge } \\
\text { Management }\end{array}$ & 1999 & Virtual \\
\hline 4 & $\begin{array}{l}\text { Centro de Investiga- } \\
\text { ción y de Estudios } \\
\text { Avanzados (Cinvestav) }\end{array}$ & $\begin{array}{c}\text { Transdisciplinary PhD, } \\
\text { Science, Technology } \\
\text { and Society }\end{array}$ & 2009 & Presential \\
\hline 5 & $\begin{array}{l}\text { El Colegio de México } \\
\text { (COLMEX) }\end{array}$ & Master in librarianship & 2010 & Presential \\
\hline 6 & $\begin{array}{l}\text { Universidad Autónoma } \\
\text { de Ciudad Juárez } \\
\text { (UACJ) }\end{array}$ & $\begin{array}{l}\text { Master/PhD } \\
\text { in Information } \\
\text { Magnagement }\end{array}$ & 2010 & Virtual \\
\hline 7 & $\begin{array}{l}\text { Universidad Autónoma } \\
\text { de Chihuahua (UACH) }\end{array}$ & $\begin{array}{c}\text { Master, librarianship } \\
\text { and Information Science }\end{array}$ & 2013 & Presential \\
\hline 8 & $\begin{array}{c}\text { Universidad Autónoma } \\
\text { de San Luis Potosí } \\
\text { (UASLP) }\end{array}$ & $\begin{array}{l}\text { Master in Information } \\
\text { Science } \\
\text { and Documentation }\end{array}$ & 2015 & Presential \\
\hline
\end{tabular}

Table 8. Relation of graduate programs in the field of informetrics

\section{DiSCUSSION AND CONCLUDING REMARKS}

The present analysis of the research production in informetrics in Mexico finds a young community of scholars with about 40 years of activity. This community originated in the first training programs on bibliothecology and information science. UNAM was pioneer in both training programs and research projects. Our analysis identified a strong research network of collaboration but with rather few dominant nodes (Luna-Morales, Luna-Morales, and Pérez-Angón, 2021). We were able to identify five scholars which had a clear influence in the development of this community: Jane 
Margaret Russell Barnard y Salvador Gorbea-Portal (Instituto de Investigaciones Bibliotecológicas. UNAM), Judith Licea de Arenas (Facultad de Filosofía y Letras, UNAM), and Eduardo Aguado López and Rosario Rogel Salazar (Universidad Autónoma del Estado de México).

While most of the research production in this area of knowledge is published in mainstream journals involving collaborations of several authors (Dorta-González and Santana-Jiménez, 2019), in the Mexican case most of the research production is published in regional journals in Spanish with few international collaborations, with just $17 \%$ of the publications involving collaborations with authors beyond the Latin American region (Luna-Morales, Luna-Morales, and Pérez-Angón, 2021). This fact is also a consequence of the large number of local authors in the production of this area of knowledge.

The maturity of a research community depends on the effective implementation of several factors: academic and experimental infrastructure, active leadership, collaborative work and the formation of new researchers through qualified graduate programs (Durand-Villalobos, 2017). Even though the field of informetrics in Latin America and Mexico has been active for about 50 years (Kreimer and Vessuri, 2018), we could identify a positive trend of the Mexican research production starting the period 2000-2018.

Our findings indicate that this research trend is a consequence of three facts: (1) an increasing number of institutions with undergraduate programs in librarianship; (2) an increase in the number of scholars involved in this area of knowledge, which were trained mostly in foreign institutions; (3) the consolidation of several research groups with experienced members of NSR. The formal requirement stablished for NSR members to maintain a continous research activity has also contributed to the steady increase in the research production in the field of metric studies of science and technology.

In the present work, we have characterized the scholar community that is active in research in the field of informetrics in Mexico. Its research output was retrieved from ten bibliometric databases. Our findings indicate a positive trend in this research production just in the period 2000-2018 in both in published documents and the respective number of generated citations. The scholars working in the area of librarianship have the largest contribution in the number of published documents $(27.2 \%)$ but not in the number of generated citations $(17.6 \%)$. The scholars working in the area of medicine had the largest fraction of generated citations $(28.7 \%)$ with a lower number of published papers $(21.6 \%)$. It is natural that the librarianship community is the most active in this research area since its work is directly related to the metric studies of science and technology. Salvador Gorbea-Portal (2013) has pointed out that metric studies of the scientific information constitute a 
new research field: librarianship. It is a multidisciplinary discipline that has involved scholars with different research interests, like engineers, physicists, mathematicians and others.

This area of knowledge has still an intense concentration of research activity in the Mexico City metropolitan area: $52.2 \%$ of the researchers, $59.4 \%$ of the Mexican production and $55.3 \%$ of the total number of citations.

On the other hand, there a substantial number of NSR members in our data sample $(54.5 \%)$, the active researchers in this area of knowledge represent a healthy variety of scientific disciplines. We were able to identify a strong network of collaboration among the members of this community. However, there is weak point in the structure of this network: there is a very few dominant nodes (less then ten).

We would like to stress that, as far we know, the present work is the first study that addresses the evolution and characterization of a local community of scholars in Latin America involved in research and training in the area of informetrics studies. Finally, we hope that the present study will be continued in future work by taking into account the following pints: analysis of the performance of new researchers coming out from the seven graduate programs identified in the present work; and the age distribution of the members of this community in order to determine the perspective of new research groups located outside the Mexico City metropolitan area. It will be interesting also to search for the production in other databases and journals in this research field which are not included in the databases analyzed.

Acknowledgments

We appreciate the support of SNI and Conacyt (proyect A1-S-9013).

\section{References}

ACM (Atlas de la Ciencia Mexicana). 2013. Indicadores por área del conocimiento 1980-2013. México: Academia Mexicana de Ciencias. http://atlasdelacienciamexicana.org/es/index-es.shtml

Almeida-Filho, Naomar, Ichiro Kawachi, Alberto Pellegrini-Filho, and J. Norberto W. Dachs. 2003. "Research on health inequalities in Latin America and the Caribbean: bibliometric analysis (1971-2000) and descriptive content analysis (19711995)." American Journal of Public Health 93 (12): 2037-2043. https://doi.org/10.2105/ajph.93.12.2037

Alonso-Gamboa, José Octavio. 2003. "Selección de revistas latinoamericanas en bases de datos: criterios utilizados en Clase y Periódica.” Biblioteca Universitaria 6 (1): 9-21. https://www.redalyc.org/pdf/285/28560103.pdf 
Ayala, Teresa. 2014. "Redes sociales, poder y participación ciudadana." Revista Austral de Ciencias Sociales 26: 23-48. https://www.redalyc.org/pdf/459/45931862002.pdf

Ball, Rafael. 2017. An Introduction to Bibliometrics. Germany: Elsevier, Chandos Publishing.

Bonilla-Marín, Marcial and Miguel Ángel Pérez-Angón. 1999. "Revistas mexicanas de investigación científica y tecnológica.” Interciencia 24 (2): 102-106.

Castillo, Alicia. 2000. "Communication and utilization of science in developing countries.” Science Communication 22 (11): 46-72. https://doi.org/10.1177/1075547000022001004

Collazo-Reyes, Francisco. 2014. "Growth of the number of indexed journals of Latin America and the Caribbean: the effect on the impact of each country." Scientometrics 98 (1): 197-209. https://doi.org/10.1007/s11192-013-1036-2

Contreras-Gómez, Leobardo Eduardo, José Luis Olivares-Vázquez, Guadalupe Palacios-Núñez, Rafael Masrmolejo-Leyva, Claudia Noemí González Brambila, Miguel Ángel Pérez Angón, and Manuel Gil-Antón. 2020. “Desconcentración del Sistema Nacional de Investigadores: geografía y estratificación. El caso de las ciencias sociales (2020-2018)." Revista de la Educación Superior 49 (193): 83-106. http://www.scielo.org.mx/scielo.php?script=sci_arttext\&pid=S0185-27602020000100083

Contreras-Gómez, Leobardo Eduardo, Rafael Baquero-Parra, Eduardo Robles-Belmont, and Miguel Ángel Pérez-Angón. 2015. "Patrones de movilidad de los físicos mexicanos en el Sistema Nacional de Investigadores.” Interciencia 40 (8): 525-532.

Cortés-Vargas, Daniel. 2007. "Medir la producción científica de los investigadores universitarios: la bibliometría y sus límites." Revista de la Educación Superior 36 (142): 43-65.

http://www.scielo.org.mx/pdf/resu/v36n142/v36n142a3.pdf

Dorta-González, Pablo and Yolanda Santana-Jiménez. 2019. "Characterizing the highly cited articles: A large-scale bibliometric analysis of the top 1\% most cited research." Malaysian Journal of Library E Information Science 24 (2): 23-39.

Duarte-Malanski, Priscila, Sandra Schiavi, and Benoit Dedieu. 2019. "Characteristics of work in agriculture scientific communities. A bibliometric review." Agronomy for Sustainable Development 39 (36).

https://doi.org/10.1007/s13593-019-0582-2

Durand-Villalobos, Juan Pablo. 2017. "Grupos de investigación consolidados en la Universidad de Sonora.” Revista Mexicana de Investigación Educativa 22 (75): 1143-1167.

Egghe, Leo and Ronald Rousseau. 1990. Introduction to Informetrics: Quantitative Methods in Library, Documentation and Information Science. Amsterdam: Elsevier.

Ekanayake, E. M. A. C., Geoffrey Shen, and Mohan M. Kumaraswamy. 2019. "Mapping the knowledge domains of value management: a bibliometric approach." Engineering Construction and Architectural Management 26 (3): 499-514. https://doi.org/10.1108/ECAM-06-2018-0252

Fischhoff, Baruch. 2019. "Evaluating science communication." Proceedings of the National Academy of Sciences of the United States of America 116 (16): 7670-7675. 
Gil-Antón, Manuel and Leobardo Eduardo Contreras-Gómez. 2017. “The National System of Researchers: ¿mirror or model?” Revista de la Educacion Superior 46 (184): 1-19.

Gorbea-Portal, Salvador. 2013. “Tendencias transdisciplinarias en los estudios métricos de la información y su relación con la gestión de la información y del conocimiento." Perspectivas em Gestão E Conhecimento, João Pessoa 3 (1): 13-27.

Gorbea-Portal, Salvador. 2016. "Una nueva perspectiva teórica de la bibliometría basada en su dimensión histórica y sus referentes temporales." Investigación Bibliotecológica 30 (70): 11-16. http://www.scielo.org.mx/scielo.php?script=sci_arttext\&pid=S0187-358X2016000300011

Hanel, Paul H. P. and David M. A. Mehler. 2019. "Beyond reporting statistical significance: Identifying informative effect sizes to improve scientific communication." Public Understanding of Science 28 (4): 468-485. https://doi.org/10.1177/0963662519834193

Haunschild, Robin and Lutz Bornmann. 2017. "How many scientific papers are mentioned in policy-related documents? An empirical investigation using Web of Science and Altmetric data." Scientometrics 110 (3): 1209-1216.

Herrero-Solana, Víctor and Claudia Ríos-Gómez. 2006. "Producción latinoamericana en biblioteconomía y documentación en el Social Science Citation Index (SSCI) 1966-2003.” Information Research 11 (2): 247-264.

Hérubel, Jean Pierre V. M. 1999. "Historical Bibliometrics: Its Purpose and Significance to the History of Disciplines." Libraries and Culture 34 (4):380-388.

Hood, Willam W. and Concepsion S. Wilson. 2001. "The literature of bibliometrics, scientometrics, and informetrics." Scientometrics 52: 290-303. https://doi.org/10.1023/A:1017919924342

Jovanovic, Milos. 2012. "A short history of early bibliometrics." NFD Information-Wissenschaft und Praxis 63 (2): 71-80.

Krauskopf, M., R. Pessot, and R. Vicuña. 1986. "Science in Latin America how much and along what lines?" Scientometrics 10 (3-4): 199-206. https://doi.org/10.1007/BF02026041

Kreimer, Pablo and Hebe Vessuri. 2018. "Latin American science, technology and society: a historical and reflexible approach." Tapuya: Latin American Science, Technology and Society 1 (1): 17-37. https://doi.org/10.1080/25729861.2017.1368622

Luna-Morales, María Elena, Evelia Luna-Morales, and Miguel Ángel Pérez-Angón. 2021. "Influence of the international collaboration in the field of metric studies of science and technology: the case of Mexico (1971-2018)." Scientometrics 126: 2485-2511. https://link.springer.com/article/10.1007/s11192-020-03522-5

Mandelis, Andreas. 2019. "Review of Scientific Instruments New Products." Review of Scientific Instruments 90 (3): 039501.

Mingers, John and Loet Leydesdorff. 2015. "A Review of Theory and Practice in Scientometrics.” European Journal of Operational Research 246 (1): 1-19. https://doi.org/10.1016/j.ejor.2015.04.002

Peralta-González, María Josefa, Maylin Frías-Guzmán, and Orlando Gregorio-Chaviano. 2015. "Criterios, clasificaciones y tendencias de los indicadores bibliométricos en la evaluación de la ciencia." Revista Cubana de Información en Ciencias de la Salud 26 (3): 290-309. 
Pérez-Angón, Miguel Ángel and Gabino Torres-Vega. 1998. "Perspectiva de la física mexicana." Interciencia 23: 163.

Peters, Isabella and Judith Bar-Ilan. 2015. "Informetrics, bibliometrics, altmetrics: $¿$ What is it all about?" Proceedings of the American Society for Information Science and Technology (April 24). https://asistdl.onlinelibrary.wiley.com/doi/full/10.1002/meet.2014.14505101015

Restrepo-Arango, Cristina and Rubén Urbizagástegui-Alvarado. 2017. "Red de co-palabras en la bibliometría mexicana." Investigación Bibliotecológica 31 (73): 17-45. http://www.scielo.org.mx/pdf/ib/v31n73/2448-8321-ib-31-73-00017.pdf

Robles-Glenn, Jorge. 1971. "La investigación mexicana y los índices extranjeros de información”. Anuario de Bibliotecología, Archivología e Informática 3 (época 2): 47-100.

Rodríguez-Miramontes, Jorge and Claudia Noemi González-Brambila. 2016. "The effect of external collaboration on research output in engineering." Scienctometrics 109 (2): 661-675. https://doi.org/10.1007/s11192-016-2054-7

Sengupta, Indranil N. 1992. "Bibliometrics, Informetrics, Scientometrics and Librametrics: An Overview.” Libri 42 (2): 75-98. https://doi.org/10.1515/libr.1992.42.2.75

Tague-Sutcliffe, Jean M. 1996. "Some perspectives on the evaluation of information retrieval systems." Journal of the American Society for Information Science 47: 1-3.

Uddin, Shahadat, Nazim Choudhury, and Md Ekramul Hossain. 2019. "A research framework to explore knowledge evolution and scholarly quantification of collaborative research." Scientometrics 119 (2): 789-803. https://doi.org/10.1007/s11192-019-03057-4

William, Evans. 2001. "Mapping Mainstream and Fringe Medicine on the Internet." Science Communication 22 (3): 292-299.

Wolfram, Dietmar. 2015. "The symbiotic relationship between information retrieval and informetrics.” Scientometrics 102: 2201-2214. https://doi.org/10.1007/s11192-014-1479-0

Youngblood, Mason and David Lahti. 2018. "A bibliometric analysis of the interdisciplinary field of cultural evolution." Palgrave communications 4 (120): 1-9. https://www.nature.com/articles/s41599-018-0175-8

Para citar este texto:

Luna-Morales, María Elena, Miguel Ángel Pérez-Angón y Evelia Luna-Morales. 2021. "Evolution of the scholar community in the area of informetrics in Mexico: 1971-2018”. Investigación Bibliotecológica: archivonomía, bibliotecología e información 35 (89): 51-78.

http://dx.doi.org/10.22201/iibi.24488321xe.2021.89.58386 


\section{Appendix}

Relation of the most cited papers by Mexican scholars in the field of metric studies (1971-2018)

\begin{tabular}{|c|c|c|c|c|c|c|}
\hline Year & Authors & Title & Source & $\begin{array}{l}\text { Document } \\
\text { Type }\end{array}$ & Citations & *Database \\
\hline 2007 & $\begin{array}{c}\text { Gonzalez-Brambila, } \\
\text { C.; Veloso, F. M. }\end{array}$ & $\begin{array}{l}\text { "The deter- } \\
\text { minants of } \\
\text { research output } \\
\text { and impact: A } \\
\text { study of Mexican } \\
\text { researchers" }\end{array}$ & $\begin{array}{c}\text { Research } \\
\text { Policy } \\
36(7): \\
\text { 1035-1051 }\end{array}$ & Article & 105 & WoS \\
\hline 2013 & $\begin{array}{c}\text { Nagata, J. M.; } \\
\text { Hernández-Ra- } \\
\text { mos, I.; Kurup, A. } \\
\text { S.; Albrecht, D.; } \\
\text { Vivas-Torrealba, C.; } \\
\text { Franco-Paredes, C. }\end{array}$ & $\begin{array}{l}\text { "Social determi- } \\
\text { nants of health } \\
\text { and seasonal } \\
\text { influenza vacci- } \\
\text { nation in adults } \\
\geq 65 \text { years: A } \\
\text { systematic re- } \\
\text { view of qualitative } \\
\text { and quantitative } \\
\text { data" }\end{array}$ & $\begin{array}{c}\text { BMC Public } \\
\text { Health } \\
13(388)\end{array}$ & Review & 99 & Scopus \\
\hline 2012 & $\begin{array}{l}\text { Barreto, S. M.; Mi- } \\
\text { randa, J. J.; Figue- } \\
\text { roa, J. P.; Schmidt, } \\
\text { M. I.; Munoz, S.; } \\
\text { Kuri-Morales, P. P.; } \\
\text { Silva, J. B. }\end{array}$ & $\begin{array}{l}\text { "Epidemiology } \\
\text { in Latin America } \\
\text { and the Carib- } \\
\text { bean: current } \\
\text { situation and } \\
\text { challenges" }\end{array}$ & $\begin{array}{l}\text { International } \\
\text { Journal of } \\
\text { Epidemio- } \\
\text { logy } \\
41 \text { (2): } 557- \\
571\end{array}$ & Article & 84 & WoS \\
\hline 2007 & Hamel, R. E. & $\begin{array}{l}\text { "The dominance } \\
\text { of English in the } \\
\text { international } \\
\text { scientific perio- } \\
\text { dical literature } \\
\text { and the future of } \\
\text { language use in } \\
\text { science" }\end{array}$ & $\begin{array}{c}\text { Aila Review } \\
20(1) \text { : } \\
53-71\end{array}$ & Article & 83 & Scopus \\
\hline 2007 & $\begin{array}{l}\text { Lowe, R. A.; Gon- } \\
\text { zalez-Brambila, C. }\end{array}$ & $\begin{array}{l}\text { "Faculty } \\
\text { entrepreneurs } \\
\text { and research } \\
\text { productivity" }\end{array}$ & $\begin{array}{c}\text { Journal of } \\
\text { Technology } \\
\text { Transfer } \\
\text { 32: 173-194 }\end{array}$ & Article & 77 & WoS \\
\hline 2009 & $\begin{array}{l}\text { Martínez-Mekler, } \\
\text { G.; Martínez, R. } \\
\text { A.; Del Río, M.-B.; } \\
\text { Mansilla, R.; } \\
\text { Miramontes, P.; } \\
\text { Cocho, G. }\end{array}$ & $\begin{array}{l}\text { "Universality of } \\
\text { rank-ordering } \\
\text { distributions } \\
\text { in the arts and } \\
\text { sciences" }\end{array}$ & $\begin{array}{c}\text { Plos One } \\
4 \text { (3): e4791 }\end{array}$ & Article & 73 & Scopus \\
\hline
\end{tabular}




\begin{tabular}{|c|c|c|c|c|c|c|}
\hline 2007 & $\begin{array}{c}\text { Mansilla, R.; } \\
\text { Koppen, E.; Cocho, } \\
\text { G.; Miramontes, P. }\end{array}$ & $\begin{array}{l}\text { "On the behavior } \\
\text { of journal impact } \\
\text { factor rank-order } \\
\text { distribution" }\end{array}$ & $\begin{array}{l}\text { Journal of } \\
\text { Informetrics } \\
1(2): 155- \\
160\end{array}$ & Article & 63 & WoS \\
\hline 2014 & $\begin{array}{c}\text { Aleman-Nava, G. } \\
\text { S.; Casiano-Flores, } \\
\text { V. H.; Carde- } \\
\text { nas-Chavez, D. } \\
\text { L.; Diaz-Chavez, } \\
\text { R.; Scarlat, N.; } \\
\text { Mahlknecht, J.; } \\
\text { Dallemand, J. F.; } \\
\text { Parra, R. }\end{array}$ & $\begin{array}{c}\text { "Renewable } \\
\text { energy research } \\
\text { progress in Mexi- } \\
\text { Co: A review" } \\
\text { (ITESM, estudio } \\
\text { de la producción } \\
\text { Tecnología del } \\
\text { agua) }\end{array}$ & $\begin{array}{c}\text { Renewable \& } \\
\text { Sustainable } \\
\text { Energy } \\
\text { Reviews } \\
\text { 32: 140-153 }\end{array}$ & Review & 62 & WoS \\
\hline 2004 & $\begin{array}{l}\text { Morales-Gonzales, } \\
\text { J. M.; Benito-Leon, } \\
\text { J.; Rivera-Navarro, } \\
\text { J.; Mitchell, A. J. }\end{array}$ & $\begin{array}{l}\text { "A systematic } \\
\text { approach to } \\
\text { analyse heal- } \\
\text { th-related quality } \\
\text { of life in multiple } \\
\text { sclerosis: the } \\
\text { GEDMA study" } \\
\text { (Universidad de } \\
\text { Veracruz, Estudio } \\
\text { de esclerosis } \\
\text { múltiple, metodo- } \\
\text { logía cuantitativa } \\
\text { y cualitativa) }\end{array}$ & $\begin{array}{l}\text { Multiple } \\
\text { Sclerosis } \\
\text { Journal } \\
10(1): \\
47-54\end{array}$ & Article & 62 & WoS \\
\hline 2001 & $\begin{array}{l}\text { Kostoff, R. N.; Del } \\
\text { Rio, J. A.; Humenik, } \\
\text { J. A.; Garcia, E. O.; } \\
\text { Ramirez, A. M. }\end{array}$ & $\begin{array}{l}\text { "Citation mining: } \\
\text { Integrating text } \\
\text { mining and } \\
\text { bibliometrics for } \\
\text { research user } \\
\text { profiling" }\end{array}$ & $\begin{array}{c}\text { JASIST } \\
52(13): \\
1148-1156\end{array}$ & Article & 57 & WoS \\
\hline 2011 & $\begin{array}{c}\text { Arechavala Vargas, } \\
\text { R. }\end{array}$ & $\begin{array}{l}\text { "Las univer- } \\
\text { sidades y el } \\
\text { desarrollo de la } \\
\text { investigación } \\
\text { científica y tecno- } \\
\text { lógica en México: } \\
\text { Una agenda de } \\
\text { investigación" }\end{array}$ & $\begin{array}{l}\text { Revista de la } \\
\text { Educacion } \\
\text { Superior } \\
40 \text { (158): } \\
41-57\end{array}$ & Article & 54 & Scielo \\
\hline 2000 & $\begin{array}{l}\text { Ramirez, A. M.; } \\
\text { Garcia, E. O.; Del } \\
\text { Rio, J. A. }\end{array}$ & $\begin{array}{l}\text { "Renormalized } \\
\text { impact factor" }\end{array}$ & $\begin{array}{l}\text { Scientome- } \\
\quad \text { trics } \\
47(3-9): 7\end{array}$ & Article & 49 & WoS \\
\hline
\end{tabular}




\begin{tabular}{|c|c|c|c|c|c|c|}
\hline 2012 & $\begin{array}{c}\text { Kaplan, W. A.; Ritz, } \\
\text { L. S.; Vitello, M.; } \\
\text { Wirtz, V. J. }\end{array}$ & $\begin{array}{l}\text { "Policies to } \\
\text { promote use of } \\
\text { generic medici- } \\
\text { nes in low and } \\
\text { middle income } \\
\text { countries: A } \\
\text { review of publi- } \\
\text { shed literature, } \\
2000-2010 "\end{array}$ & $\begin{array}{l}\text { Health Policy } \\
106(3): \\
\text { 211-224 }\end{array}$ & Review & 47 & WoS \\
\hline 2001 & $\begin{array}{l}\text { Ingwersen, P.; Lar- } \\
\text { sen, B.; Rousseau, } \\
\text { R.; Russell, J. }\end{array}$ & $\begin{array}{l}\text { "The publica- } \\
\text { tion-citation } \\
\text { matrix and its de- } \\
\text { rived quantities" }\end{array}$ & $\begin{array}{c}\text { Chinese } \\
\text { Science } \\
\text { Bulletin } \\
46: 524- \\
528\end{array}$ & $\begin{array}{l}\text { Editorial } \\
\text { Material }\end{array}$ & 46 & WoS \\
\hline 2014 & $\begin{array}{c}\text { Vessuri, H.; Gué- } \\
\text { don, J.-C.; Cetto, } \\
\text { A. M. }\end{array}$ & $\begin{array}{l}\text { "Excellence or } \\
\text { quality? Impact } \\
\text { of the current } \\
\text { competition re- } \\
\text { gime on science } \\
\text { and scientific pu- } \\
\text { blishing in Latin } \\
\text { America and its } \\
\text { implications for } \\
\text { development" }\end{array}$ & $\begin{array}{c}\text { Current } \\
\text { Sociology } \\
62(5): 647- \\
665\end{array}$ & Article & 41 & Scopus \\
\hline 2016 & $\begin{array}{c}\text { Cadenas, E.; } \\
\text { Rivera, W.; Cam- } \\
\text { pos-Amezcua, R.; } \\
\text { Heard, C. }\end{array}$ & $\begin{array}{c}\text { "Wind speed } \\
\text { prediction using a } \\
\text { univariate ARIMA } \\
\text { model and a } \\
\text { multivariate NARX } \\
\text { model" } \\
\text { (Es un estudio } \\
\text { de impacto de } \\
\text { variables, varias } \\
\text { instituciones de } \\
\text { México) }\end{array}$ & $\begin{array}{l}\text { Energies } \\
9(2): 109 \text { - }\end{array}$ & Article & 40 & Scopus \\
\hline 2013 & $\begin{array}{l}\text { Gonzalez-Brambila, } \\
\text { C. N.; Veloso, F. M.; } \\
\text { Krackhardt, D. }\end{array}$ & $\begin{array}{l}\text { "The impact of } \\
\text { network embe- } \\
\text { ddedness on } \\
\text { research output" }\end{array}$ & $\begin{array}{c}\text { Research } \\
\text { Policy } \\
42(9): \\
1555-1567\end{array}$ & Article & 39 & WoS \\
\hline 2010 & $\begin{array}{l}\text { Olivas-Avila, J. A.; } \\
\text { Musi-Lechuga, B. }\end{array}$ & $\begin{array}{l}\text { "Analysis of the } \\
\text { production of } \\
\text { psychology pro- } \\
\text { fessors in Spain } \\
\text { in journal articles } \\
\text { of the Web of } \\
\text { Science" }\end{array}$ & $\begin{array}{c}\text { Psicothema } \\
23(2): 267- \\
273\end{array}$ & Article & 36 & WoS \\
\hline
\end{tabular}




\begin{tabular}{|c|c|c|c|c|c|c|}
\hline 2009 & $\begin{array}{l}\text { Musi-Lechuga B., } \\
\text { Olivas-Ávila J.A., } \\
\text { Buela-Casal G. }\end{array}$ & $\begin{array}{c}\text { "Producción } \\
\text { científica de los } \\
\text { programas de } \\
\text { Doctorado en } \\
\text { Psicología Clínica } \\
\text { y de la Salud de } \\
\text { España" }\end{array}$ & $\begin{array}{l}\text { International } \\
\text { Journal } \\
\text { of Clinical } \\
\text { and Health } \\
\text { Psychology } \\
9(1): 161- \\
173\end{array}$ & Article & 36 & Scopus \\
\hline 2000 & Urzua, C. M. & $\begin{array}{l}\text { "A simple and } \\
\text { efficient test for } \\
\text { Zipf's law" }\end{array}$ & $\begin{array}{c}\text { Economics } \\
\text { Letters } \\
66 \text { (3): } 257- \\
260 \\
\end{array}$ & Article & 35 & WoS \\
\hline 2014 & Collazo-Reyes, F. & $\begin{array}{l}\text { "Growth of } \\
\text { the number of } \\
\text { indexed journals } \\
\text { of Latin America } \\
\text { and the Carib- } \\
\text { bean: the effect } \\
\text { on the impact of } \\
\text { each country" }\end{array}$ & $\begin{array}{c}\text { Scientome- } \\
\quad \text { trics } \\
98: 197-209\end{array}$ & Article & 34 & WoS \\
\hline 1995 & $\begin{array}{c}\text { Lozoya, X.; } \\
\text { Rivera-Arce, E.; } \\
\text { Dominguez, F.; } \\
\text { Arellano, M. L.; } \\
\text { Muñoz, O. }\end{array}$ & $\begin{array}{l}\text { "Archives of me- } \\
\text { dical research: } \\
\text { An historical and } \\
\text { subject coverage } \\
\text { overview" }\end{array}$ & $\begin{array}{l}\text { Archives } \\
\text { of Medical } \\
\text { Research } \\
\text { 26: S1-S5 }\end{array}$ & Article & 33 & WoS \\
\hline 2010 & $\begin{array}{l}\text { Li, W. T.; Miramon- } \\
\text { tes, P.; Cocho, G. }\end{array}$ & $\begin{array}{l}\text { "Fitting Ranked } \\
\text { Linguistic Data } \\
\text { with Two-Para- } \\
\text { meter Functions" }\end{array}$ & $\begin{array}{c}\text { Entropy } \\
12(7): \\
1743-1764\end{array}$ & Article & 31 & WoS \\
\hline 2008 & $\begin{array}{l}\text { Naumis G. G.; } \\
\text { Cocho G. }\end{array}$ & $\begin{array}{l}\text { "Tail univer- } \\
\text { salities in rank } \\
\text { distributions } \\
\text { as an algebraic } \\
\text { problem: The be- } \\
\text { ta-like function" }\end{array}$ & $\begin{array}{c}\text { Physica A } \\
387(1): \\
84-96\end{array}$ & Article & 30 & Scopus \\
\hline
\end{tabular}

* This column includes the databases that were used to retrieve articles and number of citations 